\title{
65. MINERALOGY AND CHEMISTRY OF SECONDARY PHASES IN SOME BASALTIC ROCKS FROM DSDP LEG 37
}

\author{
C.M. Scarfe and D.G.W. Smith, Department of Geology, University of Alberta, Edmonton, Alberta, Canada
}

\section{INTRODUCTION}

Secondary minerals in basalts and basaltic breccias from Holes 332A, 332B, 333A, and Site 335 from DSDP Leg 37 provide information about the alteration of the volcanic layer of the oceanic crust. Previous work has stressed changes in bulk rock composition resulting from seawater-rock alteration (e.g., Hart et al., 1974); however, with a few exceptions (e.g., Bass et al., 1973; Bass, 1976), detailed studies of the mineralogical evidence for these changes have not been undertaken. A clear understanding of the alteration processes, and by implication the nature of the geochemical balance between seawater and the oceanic crust (e.g., Hart, 1970; Muehlenbachs and Clayton, 1976) depends on the mineralogical evidence.

\section{METHODS}

Standard petrographic and X-ray diffraction methods were used for identification purposes. Quantitative chemical analyses were obtained using an ARL EMX microprobe fitted with an Ortec energydispersive spectrometer. Methods used for background shaping and scaling, overlap corrections, and adjustment for instrumental drift have been described by Smith (1975), Smith et al. (1975), and Smith and Gold (1976). Normal operating conditions were $15-\mathrm{kV}$ operating voltage, 30-nA probe current, and 400-sec counting times. The limit of detection using the above methods is $\sim 500 \mathrm{ppm}$, and accuracies for major and minor elements are comparable to wavelength dispersive analysis. Strontium, which is masked by the Si K peak in the energy-dispersive spectrum, was checked by wavelength dispersive methods.

Because of sodium mobility, special methods were used for the analysis of zeolites. A beam current of 20 $\mathrm{nA}$, counting times of $100 \mathrm{sec}$, and a moving sample technique were used to avoid sample damage. In addition, to ensure homogeneous areas for analysis, X-ray scanning photographs were taken of each zeolite analyzed for the three major charge-balancing cations, $\mathrm{Na}, \mathrm{K}$, and $\mathrm{Ca}$.

\section{RESULTS}

Table 1 summarizes the results of petrographic, Xray, and microprobe analyses. Samples (10-50 g) were selected for their high degree of alteration. They are basalts and basaltic breccias which have undergone varying degrees of alteration estimated to be between $10 \%-75 \%$. Secondary phases include carbonates, zeolites, clays, palagonite, and hydrated Fe-oxides.

\section{Glass and Palagonite}

Fresh glass fragments with palagonite rims occur in all holes (Table 1 and Plate 1, Figure 1). In some cases the glass has been completely altered, the palagonite exhibiting concentric bands of birefringent, cryptocrystalline material. X-ray powder diffraction patterns of this material, however, are poorly resolved and give no clear identification of the mineralogy.

Representative analyses of glass and palagonite are given in Table 2. Fresh glass is tholeiitic in composition and similar to average Atlantic Ridge tholeiite (Melson and Thompson, 1971). Alteration of fresh glass to palagonite involves the addition of $\mathrm{H}_{2} \mathrm{O}, \mathrm{K}_{2} \mathrm{O}$, and total $\mathrm{Fe}$, and the loss of $\mathrm{SiO}_{2}, \mathrm{Al}_{2} \mathrm{O}_{3}, \mathrm{CaO}, \mathrm{MgO}$, and $\mathrm{Na}_{2} \mathrm{O}$. Since there is no textural evidence of expansion or contraction during palagonitization, these gains and losses are calculated on the assumption that alteration takes place at constant volume (see also Hay and Iijima, 1968; Muehlenbachs and Clayton, 1972).

\section{Carbonates}

The carbonate is usually calcite and occurs in veins, cavities, or vesicles. Calcites contain $\sim 5 \mathrm{~mol} \% \mathrm{MgCO}_{3}$ and only traces of $\mathrm{FeCO}_{3}$ and $\mathrm{MnCO}_{3}$. One sample (332B-28-1, 67-70 cm) contains both calcite and siderite. The latter is present as a vesicle lining in the form of encrustations exhibiting radial structure in two generations (Plate 1, Figure 2). The $\mathrm{CaCO}_{3}$ content of the siderite $(\sim 15 \mathrm{~mol} \%)$ is surprisingly high, suggesting formation at temperatures in excess of $400^{\circ} \mathrm{C}$ (Rosenberg, 1967) during cooling of the lava pile.

\section{Zeolites}

Zeolites occur in some samples as infilling between breccia fragments, while in others they are confined to small veins, cavities, or vesicles. The habit ranges from granular or blocky to prismatic. Where prismatic crystals are abundant, they commonly form radiating clusters with individual crystals up to $0.5 \mathrm{~mm}$ in length (Plate 1, Figures 3 and 4).

Based upon X-ray identification, with confirmation by microprobe analysis, phillipsite is present in all four holes (Table 1). Representative microprobe analyses are given in Table 3 . Based on 72 oxygens, ideally $\mathrm{Si}+$ $\mathrm{Al}$ should be close to 36 and the sum of $2 \mathrm{Ca}+\mathrm{Na}+\mathrm{K}$ should equal Al (see also discussion by Steele et al., 1975). Since these phillipsites are somewhat deficient in $\mathrm{Al}$ and $\mathrm{Ca}$ and are enriched in $\mathrm{Si}$ and alkalis, departures from the ideal composition are attributed to replacements of the type $\mathrm{CaAl} \rightleftharpoons(\mathrm{Na}, \mathrm{K}) \mathrm{Si}$. These deviations from ideality are not surprising, since a wide range of $\mathrm{Si}: \mathrm{Al}$ ratios and concentrations of $\mathrm{Ca}, \mathrm{Na}$, and 
TABLE 1

Summary of Secondary Minerals Identified in DSDP Leg 37 Basalts

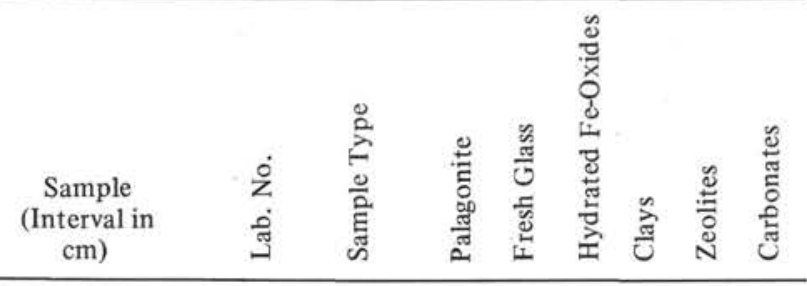

Hole 332A

\begin{tabular}{|c|c|c|c|c|}
\hline $190 \quad$ B & $\mathrm{x}$ & & $\mathrm{x}$ & \\
\hline GFCM & $\mathrm{x}$ & $\mathrm{x}$ & & $\mathrm{x}$ \\
\hline VPB & $\mathrm{x}$ & & & $\mathrm{x}$ \\
\hline VBB & & & $\mathrm{x}$ & $x$ \\
\hline PB & & & & $\mathrm{x}$ \\
\hline
\end{tabular}

$26-2,10-12$ (2)

$30-1,22-24$

$31-3,20-22(1 \mathrm{C})$

40-3,106-109 (8B)

194 PB

Hole 332B

\begin{tabular}{|c|c|c|c|c|c|c|c|}
\hline $3-1 \sim 108(8 \mathrm{~A})$ & 195 & PB & & & & $\mathrm{x}$ & \\
\hline $21-1,55-59(3)$ & 196 & PB & & & & $\mathrm{x}$ & $\mathrm{x}$ \\
\hline $21-1,55-59$ (3) & 197 & BB & $\mathrm{x}$ & $\mathrm{x}$ & $\mathrm{x}$ & & \\
\hline $28-1,8-10$ & 198 & VB & & & & $\mathrm{x}$ & $\mathrm{x}$ \\
\hline $28-1,67-70(7)$ & 199 & VB & & & & $\mathrm{x}$ & \\
\hline $36-5,5-7(1)$ & 200 & GFCM & $\mathrm{x}$ & $\mathrm{x}$ & & & $\mathrm{x}$ \\
\hline $36-5,5-7(1)$ & 201 & PB & & & $\mathrm{x}$ & & $\mathrm{x}$ \\
\hline $44-5,16-18(2 A)$ & 202 & PB & & & & & $\mathrm{x}$ \\
\hline $44-6,40-42$ & 203 & VB & & & & & \\
\hline $45-1,132-134(13)$ & 204 & BB & $\mathrm{x}$ & $\mathrm{x}$ & & & $\mathrm{x}$ \\
\hline
\end{tabular}

Hole 333A

\begin{tabular}{|c|c|c|c|c|c|c|c|c|}
\hline $3-1 \sim 69$ (7B) & 205 & PB & & & & $\mathrm{x}$ & & $\mathrm{x}$ \\
\hline $5-2 \sim 17$ (3) & 206 & BB & $\mathrm{x}$ & $\mathrm{x}$ & & $\mathrm{x}$ & & $\mathrm{x}$ \\
\hline $5-2 \sim 17(3)$ & 207 & BB & $\mathrm{x}$ & $\mathrm{x}$ & & & & \\
\hline $6-1 \sim 94(12)$ & 208 & BB & & & $\mathrm{x}$ & & & \\
\hline $6-1,140-143(18)$ & 209 & BB & & & $\mathrm{x}$ & & & $\mathrm{x}$ \\
\hline $7-1 \sim 100(14)$ & 210 & BB & & & & $\mathrm{x}$ & & \\
\hline $8-1 \sim 123(15)$ & 211 & B & $\mathrm{x}$ & $\mathrm{x}$ & & $\mathrm{x}$ & $\mathrm{x}$ & $\mathrm{x}$ \\
\hline $8-4 \sim 106(11)$ & 212 & VBB & & & $\mathrm{x}$ & $\mathrm{x}$ & $\mathrm{x}$ & \\
\hline $8-7 \sim 74(7)$ & 213 & BB & & & & & $\mathrm{x}$ & $\mathrm{x}$ \\
\hline $9-1 \sim 90(11 \mathrm{~A})$ & 214 & BB & $\mathrm{x}$ & $\mathrm{x}$ & $\mathrm{x}$ & & $\mathrm{x}$ & $\mathrm{x}$ \\
\hline $0-1 \sim 13(2)$ & 215 & $\mathrm{~B}$ & & & & $\mathrm{x}$ & & \\
\hline
\end{tabular}

Site 335

6-6,22-24 (2)

220 GFCM $\mathrm{x} \quad \mathrm{x}$

$\mathrm{x} \quad \mathrm{x}$

Note: $\mathrm{B}=$ Basalt $; \mathrm{BB}=$ Basaltic breccia; $\mathrm{GF}=$ Glass fragments; $\mathrm{P}=$ Abundant phenocrysts; $\mathrm{V}=$ Abundant vesicles; $\mathrm{CM}=\mathrm{Calcar}-$ eous matrix (sedimentary).

TABLE 2

Representative Microprobe Analyses of Glass and Palagonite

\begin{tabular}{lrrrrcccc}
\hline & $\mathrm{a}$ & $\mathrm{b}$ & $\mathrm{c}$ & $\mathrm{d}$ & $\mathrm{e}$ & $\mathrm{f}$ & $\mathrm{g}$ & $\mathrm{h}$ \\
\hline $\mathrm{Hole}$ & \multicolumn{1}{c}{$332 \mathrm{~A}$} & \multicolumn{1}{c}{$332 \mathrm{~B}$} & \multicolumn{1}{c}{$333 \mathrm{~A}$} & \multicolumn{1}{c}{335} & $332 \mathrm{~A}$ & $332 \mathrm{~B}$ & $333 \mathrm{~A}$ & 335 \\
\hline $\mathrm{Lab} \mathrm{No}$. & 191 & 197 & \multicolumn{1}{c}{207} & 220 & $191 \mathrm{E} 4$ & $197 \mathrm{~A}$ & $207 \mathrm{~A} 4$ & $220 \mathrm{~A} 2$ \\
\hline $\mathrm{SiO}_{2}$ & 49.0 & 48.9 & 50.0 & 49.3 & 44.4 & 35.9 & 45.3 & 42.6 \\
$\mathrm{TiO}_{2}$ & 1.4 & 0.8 & 1.5 & 1.2 & 2.9 & 1.4 & 2.0 & 2.2 \\
$\mathrm{Al}_{2} \mathrm{O}_{3}$ & 13.8 & 15.9 & 14.2 & 15.5 & 9.4 & 12.5 & 11.7 & 12.1 \\
$\mathrm{FeO}^{*}$ & 10.1 & 8.8 & 11.2 & 9.4 & 19.0 & 16.5 & 17.0 & 17.0 \\
$\mathrm{MnO}$ & 0.2 & 0.2 & 0.1 & 0.1 & - & - & - & - \\
$\mathrm{MgO}$ & 7.3 & 9.1 & 5.9 & 10.1 & 4.1 & 3.0 & 3.8 & 4.9 \\
$\mathrm{CaO}$ & 11.6 & 12.4 & 11.5 & 11.7 & 1.1 & 1.1 & 2.6 & 1.1 \\
$\mathrm{Na} 2 \mathrm{O}$ & 1.9 & 1.8 & 2.5 & 2.5 & 0.2 & 0.5 & 0.5 & 1.9 \\
$\mathrm{~K}_{2} \mathrm{O}$ & 0.2 & - & 0.2 & 0.2 & 3.3 & 1.9 & 2.7 & 3.0 \\
\hline Total & 95.5 & 97.9 & 97.1 & 100.0 & 84.4 & 72.8 & 85.6 & 84.8 \\
\hline
\end{tabular}

Note: Refer to Table 1 for DSDP Sample No ; a-d: fresh glass (averages); $\mathrm{e}$-h: palagonite; $\mathrm{FeO} *$ total iron calculated as $\mathrm{FeO}$. 
TABLE 3

Representative Microprobe

Analyses of Phillipsites

\begin{tabular}{lccc}
\hline \multicolumn{1}{c}{ Hole } & $332 \mathrm{~A}$ & $332 \mathrm{~B}$ & $333 \mathrm{~A}$ \\
\hline $\mathrm{Lab}$ No. & $194 \mathrm{E}$ & $198 \mathrm{~A}$ & $213 \mathrm{~A}$ \\
\hline $\mathrm{SiO}_{2}$ & 53.0 & 50.8 & 51.0 \\
$\mathrm{Al}_{2} \mathrm{O}_{3}$ & 17.0 & 18.4 & 18.3 \\
$\mathrm{Fe}_{2} \mathrm{O}_{3} *$ & 0.3 & 0.2 & 0.2 \\
$\mathrm{MgO}$ & 0.1 & - & - \\
$\mathrm{CaO}$ & 0.5 & 0.3 & 0.5 \\
$\mathrm{Na}_{2} \mathrm{O}$ & 5.7 & 4.1 & 5.5 \\
$\mathrm{~K}_{2} \mathrm{O}$ & 4.0 & 6.3 & 5.4 \\
\hline Total & 80.6 & 80.1 & 80.9 \\
\hline
\end{tabular}

Cations per 72 oxygens

\begin{tabular}{lrcc}
$\mathrm{Si}$ & 26.3 & 25.6 & 25.5 \\
$\mathrm{Al}$ & 9.9 & 10.9 & 10.8 \\
$\mathrm{Fe}^{3+}$ & 0.1 & 0.1 & 0.1 \\
$\mathrm{Mg}$ & 0.1 & - & - \\
$\mathrm{Ca}$ & 0.3 & 0.2 & 0.3 \\
$\mathrm{Na}$ & 5.5 & 4.0 & 5.3 \\
$\mathrm{~K}$ & 2.5 & 4.1 & 3.4 \\
\hline
\end{tabular}

Note: Refer to Table 1 for DSDP Sample $\mathrm{No} ; \mathrm{Fe}_{2} \mathrm{O}_{3}$ * total iron calculated as $\mathrm{Fe}_{2} \mathrm{O}_{3}$.

$\mathrm{K}$ have been found in phillipsites in both sedimentary and nonsedimentary environments (Hay, 1966; Iijima and Harada, 1969).

\section{Clays}

Clays occur in small veins, clots, or as vesicle linings (Plate 1, Figures 5 and 6). Frequently the clays are brown or green in color. X-ray powder patterns of unglycolated samples were poorly resolved and separation into two categories was made solely on differences in chemical analyses (Table 4). The brown Mg-rich type is saponite, while the green $\mathrm{Fe}-\mathrm{K}$-rich type is difficult to identify further.

\section{DISCUSSION}

Phillipsite is a common zeolite in sea-floor sediments (Cronan, 1974) and in basalts of the oceanic crust (Bass, 1975). Phillipsite forms at temperatures well below $150^{\circ}-200^{\circ} \mathrm{C}$ (Miyashiro and Shido, 1970). Oxygen isotope analyses of calcite in Leg 37 basalts (Muehlenbachs, this volume) and calcite and smectites in Leg 34 basalts (Seyfried et al., 1976; Muehlenbachs, 1976) indicate sea-floor alteration takes place at temperatures as low as $4^{\circ} \mathrm{C}$. The oxygen isotope work further shows that low temperature alteration of Leg 37 basalts caused by circulating seawater penetrates to the bottom of Hole 332B, a depth of 583 meters below the sediment-basalt interface. Thus, over the $13 \mathrm{~m} . y$. period sampled in Leg 37, substantial volumes of cold seawater passed through the basalts of oceanic layer 2 .

If the basalts of Leg 37 are typical of the oceanic crust, the high $\mathrm{K}$-content of zeolites, palagonite, and some clays suggests that significant amounts of $\mathrm{K}$ are removed from seawater by these secondary minerals.
TABLE 4

Representative Microprobe Analyses of Clay Minerals

\begin{tabular}{lrr}
\hline \multicolumn{1}{c}{ Hole } & $332 \mathrm{~B}$ & $332 \mathrm{~B}$ \\
\hline $\mathrm{Lab}$ No. & $195 \mathrm{H}$ & $199 \mathrm{D}$ \\
\hline $\mathrm{SiO}_{2}$ & 47.2 & 47.3 \\
$\mathrm{Al}_{2} \mathrm{O}_{3}$ & 7.0 & 3.3 \\
$\mathrm{Fe}_{2} \mathrm{O}_{3} *$ & 8.7 & 32.8 \\
$\mathrm{MgO}$ & 22.7 & 2.4 \\
$\mathrm{CaO}$ & 1.2 & 0.8 \\
$\mathrm{Na}_{2} \mathrm{O}$ & 0.1 & 0.2 \\
$\mathrm{~K}_{2} \mathrm{O}$ & 0.6 & 4.9 \\
\hline Total & 87.5 & 91.7 \\
\hline
\end{tabular}

Cations per 22 oxygens

$\begin{array}{lcc}\mathrm{Si} & 6.8 & 7.2 \\ \mathrm{Al} & 1.2 & 0.6 \\ \mathrm{Fe}^{3+} & 0.9 & 3.7 \\ \mathrm{Mg} & 4.9 & 0.5 \\ \mathrm{Ca} & 0.2 & 0.1 \\ \mathrm{Na} & - & 0.1 \\ \mathrm{~K} & 0.1 & 0.9\end{array}$

Note: Refer to Table 1 for DSDP Sample $\mathrm{No} ; \mathrm{Fe}_{2} \mathrm{O}_{3} *$ total iron calculated as $\mathrm{Fe}_{2} \mathrm{O}_{3}$.

\section{SUMMARY}

Basalts of DSDP Leg 37 have been altered by cold $\left(4^{\circ} \mathrm{C}\right)$ seawater to a depth of nearly 600 meters below the sediment-basalt interface. Secondary minerals formed during alteration include phillipsite, calcite, saponite, an Fe-K-rich clay, and hydrated Fe-oxides. Siderite found in one sample may have formed at temperatures above $400^{\circ} \mathrm{C}$ during cooling of the lava pile. Since palagonite, phillipsite, and some clays show considerable enrichment in $\mathrm{K}$ relative to the host basalt, it is suggested that significant amounts of $\mathrm{K}$ are removed from seawater annually by these minerals.

\section{ACKNOWLEDGMENTS}

We thank S.P. Goff, T.S. Hamilton, C. Held, S. Launspach, D.A. Tomlinson, and K. Schimann for assistance during various parts of the study. R.StJ. Lambert and K. Muehlenbachs are thanked for comments and criticism. Financial support was provided by NRC Grant DAG-1.

\section{REFERENCES}

Bass, M.N., 1975. Secondary minerals in oceanic basalts: Carnegie Inst. Washington Yearbook, v. 74, p. 234-240. 1976. Secondary minerals in oceanic basalt, with reference to Leg 34, Deep Sea Drilling Project. In Yeats, R.S., Hart, S.R., et al., Initial Reports of the Deep Sea Drilling Project, Volume 34: Washington (U.S. Government Printing Office), p. 393-432.

Bass, M.N., Moberly, R., Rhodes, J.M., Shih, C.S., and Church, S.E., 1973. Volcanic rocks cored in the central Pacific, Leg 17, Deep Sea Drilling Project: Am. Geophys. Union Trans., v. 54, p. 991-995.

Cronan, D.S., 1974. Authigenic minerals in deep-sea sediments. In Goldberg, E. D. (Ed.), The Sea, vol. 5: New York (Wiley-Interscience), p. 491-525.

Hart, R., 1970. Chemical exchange between sea water and deep ocean basalts: Earth Planet. Sci. Lett., v. 9, p. 269279. 
Hart, S.R., Erlank, A.J., and Kable, E.J.D., 1974. Sea floor basalt alteration: some chemical and $\mathrm{Sr}$ isotopic effects: Contrib. Mineral. Petrol., v. 44, p. 219-230.

Hay, R.L., 1966. Zeolites and zeolitic reactions in sedimentary rocks: Geol. Soc. Am. Spec. Paper 85 .

Hay, R.L. and Iijima, A., 1968. Petrology of palagonite tuffs of Koko Craters, Oahu, Hawaii: Contrib. Mineral. Petrol., v. 17, p. 141-154.

Iijima, A. and Harada, K., 1969. Authigenic zeolites in zeolitic palagonite tuffs on Oahu, Hawaii: Am. Mineralogist, v. 54 , p. $182-197$.

Melson, W.G. and Thompson, G., 1971. Petrology of a transform fault zone and adjacent ridge segments. Phil. Trans. Roy. Soc. London, Ser. A, v. 268, p. 423-441.

Miyashiro, A. and Shido, F., 1970. Progressive metamorphism in zeolite assemblages: Lithos, v. 3, p. 251-260.

Muehlenbachs, K., 1976. Oxygen isotope geochemistry of DSDP Leg 34 basalts. In Yeats, R.S., Hart, S.R., et al., Initial Reports of the Deep Sea Drilling Project, Volume 34: Washington (U.S. Government Printing Office), p. 337-339.

Muehlenbachs, K. and Clayton, R.N., 1972. Oxygen isotope studies of fresh and weathered submarine basalts: Canadian J. Earth Sci., v. 9, p. 172-184.

, 1976. Oxygen isotope composition of the oceanic crust and its bearing on sea water: J. Geophys. Res, v. 81 , p. $4365-4369$.
Rosenberg, P.E., 1967. Subsolidus relations in the system $\mathrm{CaCO}_{3}-\mathrm{MgCO}_{3}-\mathrm{FeCO}_{3}$ between $350^{\circ}$ and $550^{\circ} \mathrm{C}$ : $\mathrm{Am}$. Mineralogist, v. 52, p. 787-796.

Seyfried, W.E., Shanks, W.C., and Bischoff, J.L., 1976. Alteration and vein formation in Site 321 basalts. In Yeats, R.S., Hart, S.R., et al., Initial Reports of the Deep Sea Drilling Project, Volume 34: Washington (U.S. Government Printing Office), p. 385-392.

Smith, D.G.W., 1975. An approach to fully quantitative energy dispersive electron microprobe analysis: 10th Ann. Conf. Microbeam Analysis Society, Proc., Las Vegas, p. 21A-21D.

Smith, D.G.W. and Gold, C.M., 1976. A scheme for fully quantitative energy dispersive microprobe analysis. In Gould, R.W., Barrett, C.S., Newkirk, J.B., Ruud, C.O. (Eds.), Advances in X-ray Analysis, v. 19: Dubuque, Iowa (Kendall/Hunt Publishing Company), p. 191-201.

Smith, D.G.W., Gold, C.M., and Tomlinson, D.A. 1975. The atomic number dependence of the X-ray continuum intensity and the practical calculations of background in energy dispersive electron microprobe analysis: X-ray Spectrom., v. 4 , p. $149-156$.

Steele, I.M., Smith, J.V., Pluth, J.J., and Solberg, T.N., 1975. Quantitative analysis of zeolites using an energy dispersive system: 10th Ann. Conf. Microbeam Analysis Society, Proc., Las Vegas, p. 37A-37D. 


\section{PLATE 1 \\ Photomicrographs of secondary minerals and glass}

Figure 1 Fresh glass with palagonite rim (332B-21-1, 55-59 $\mathrm{cm})$. Plane polarized light.

Figure 2 Siderite lining vesicle (332B-28-1, 67-70 cm). Plane polarized light.

Figure 3 Colorless prismatic phillipsite infilling between basalt fragments (333A-8-7, $\sim 74 \mathrm{~cm})$. Plane polarized light.

Figure 4 Colorless prismatic phillipsite filling vesicle (332B$44-5,16-18 \mathrm{~cm})$. Plane polarized light.

Figure 5 Saponite filling vesicle (332B-3-1, $108 \mathrm{~cm}$ ). Plane polarized light.

Figure $6 \quad$ Fe-K-rich clay lining vesicle $(333 \mathrm{~A}-3-1, \sim 69 \mathrm{~cm})$. Plane polarized light. 
PLATE 1

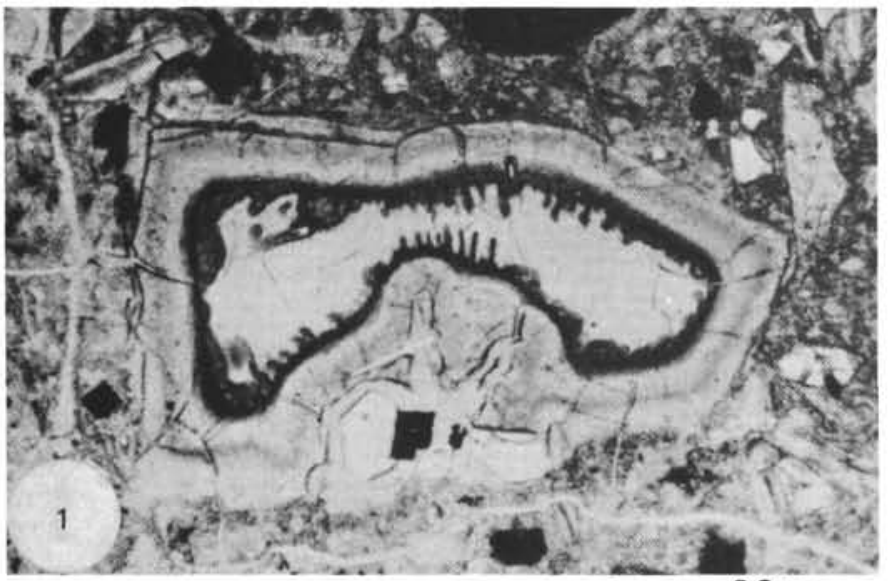

$0.3 \mathrm{~mm}$

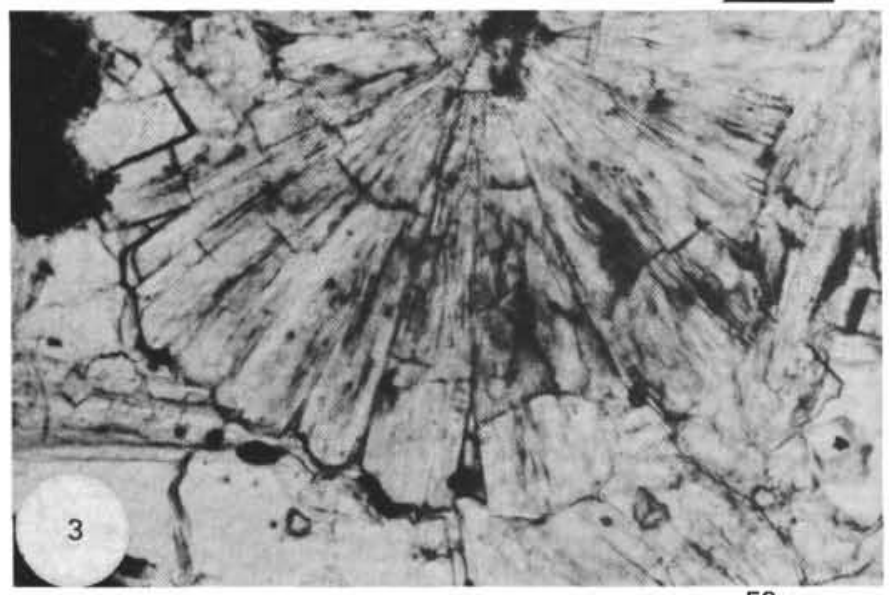

$50 \mu \mathrm{m}$

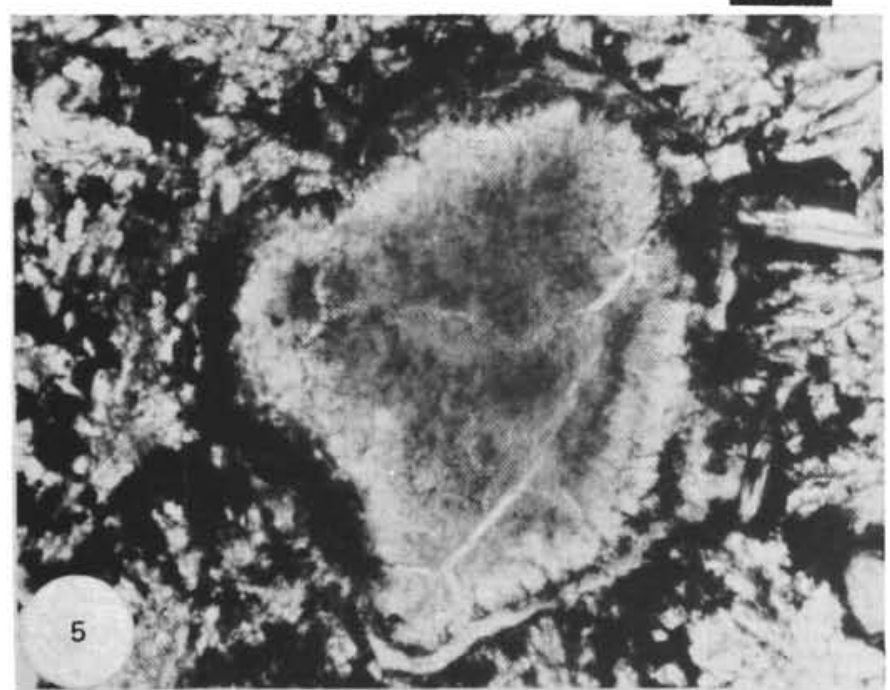

$0.1 \mathrm{~mm}$

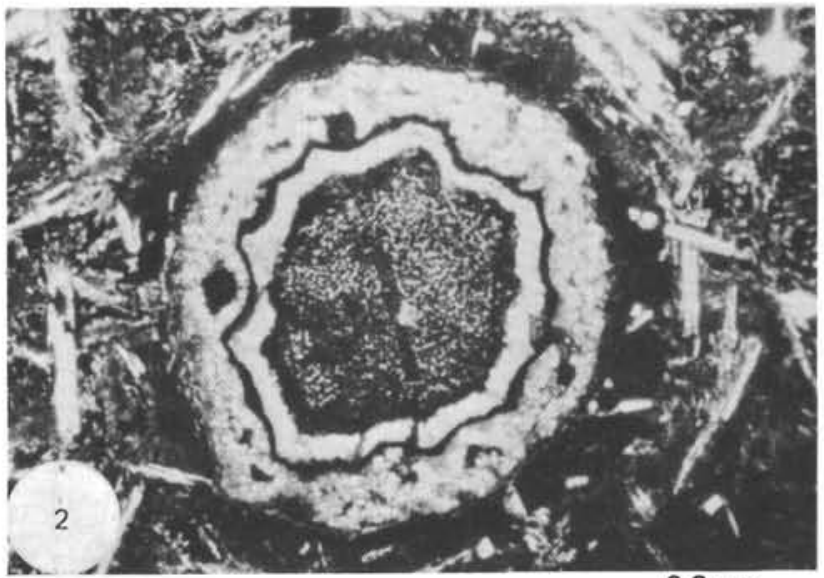

$0.3 \mathrm{~mm}$

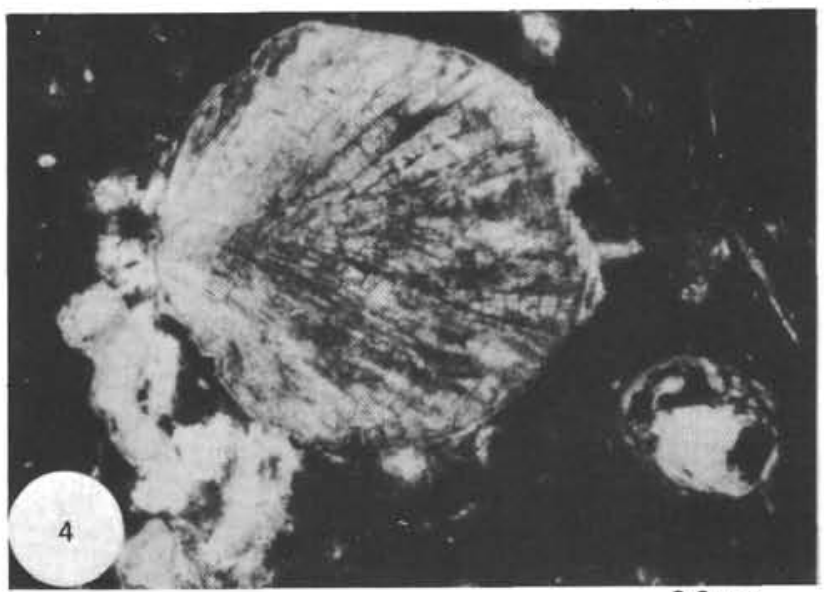

$0.2 \mathrm{~mm}$

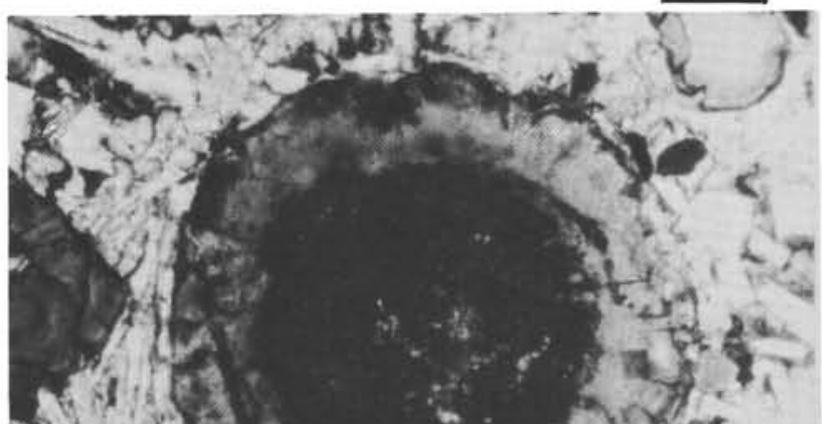

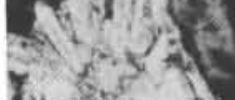

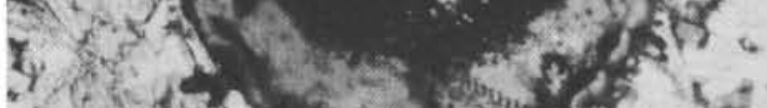
(4) 6 (3) $0.2 \mathrm{~mm}$ 